\title{
Work Engagement pada Petugas Layanan Work Engagement on Service Officer
}

\author{
Della Belinda ${ }^{1}$, Lisa Adziani ${ }^{2}$, Fendy Suhariadi ${ }^{3}$, Rini Sugiarti ${ }^{4}$ \\ ${ }^{1234}$ Fakultas Psikologi, Magister Psikologi, Universitas Semarang \\ Jl. Soekarno Hatta, Tlogosari Kulon, Pedurungan, Kota Semarang, Jawa Tengah 59160 \\ 12dee.belinda24@gmail.com
}

Article History:

Received

2021-10-08

Review

2021-12-13

Revised

2021-12-21

Accepted

2021-12-22

Published

2021-12-28
Abstract. Work engagement is still an interesting topic to research until now, because employees are an important aspect to ensure the organization can develop or not. Therefore, the organization start paying more attention to humans as human capital to be managed seriously. Research on work engagement in the public sector has attracted quite a lot of attention. Public service employees have different characteristics from other sector employees, both from work patterns and from the work environment. Several research results show that work engagement is heavily influenced by internal factors, but external factors also have an important role in influencing employee work engagement.

Keywords : work engagement

Abstrak. Work engagement masih menjadi topik yang menarik untuk diteliti sampai dengan saat ini, karena pegawai menjadi aspek penting untuk memastikan organisasi dapat berkembang ataupun tidak. Oleh karena itu organisasi mulai memberikan perhatian yang lebih kepada manusia sebagai human capital untuk dikelola secara sungguh-sungguh. Penelitian work engagement di sektor publik cukup banyak menarik perhatian. Pegawai pelayanan publik memiliki karakteristik yang berbeda dengan pegawai sektor lainnya, baik dari pola kerja maupun dari lingkungan pekerjaan.Beberapa hasil penelitian menunjukkan bahwa work engagement banyak dipengaruhi oleh faktor internal, namun faktor ekternal juga mempunyai peran penting dalam mempengaruhi work engagement pegawai.

Kata kunci : work engagement

\section{Pendahuluan}

Pada era modern ini, memiliki sumber daya manusia yang unggul saja tidak cukup untuk menghadapi persaingan, karenanya organisasi tidak hanya merekrut dan mempertahankan pegawai yang memiliki talenta saja. Organisasi membutuhkan sumber daya manusia yang terikat secara emosional terhadap organisasi ataupun pekerjaan mereka, sehingga mereka akan senantiasa memberikan usaha yang maksimal setiap kali melakukan pekerjaan (Jin \& McDonald, 2017). Keterlibatan pikiran dan emosi positif pegawai terhadap pekerjaan, disebut dengan work engagement. 
Work engagement menjadi salah satu penentu atas keberhasilan suatu organisasi dalam mencapai target pekerjaan atau organisasi. Work engagement merupakan konsep yang banyak ditemukan baik dalam dunia psikologis, dunia manajemen ataupun dunia akademisi. Bakker dan Leiter (2010) menjelaskan bahwa work engagement adalah sikap positif yang ditunjukan dengan perasaan puas terhadap pekerjaan dan diyakini dapat menghindari perilaku menunda suatu pekerjaan.

Inti dari work engagement adalah adanya kesediaan untuk mendedikasikan diri secara psikologis dalam bekerja (Schaufeli, 2013). Pegawai yang memiliki work engagement akan mencintai pekerjaan mereka, mereka tidak akan menyerah dan terus menyelesaikan pekerjaan mereka walaupun menghadapi banyak kesulitan. Sejalan dengan hal ini, Bakker (2017) menyatakan bahwa pegawai yang memiliki work engagement akan cenderung produktif, mempunyai keinginan bekerja yang lebih tinggi, lebih peka dan mudah beradaptasi terhadap hal-hal baru. Bakker dan Leiter (2010) juga menegaskan dengan adanya work engagement pegawai akan lebih memiliki perasaan bahagia dan lebih menikmati pekerjaan tanpa adanya tekanan ataupun paksaan.

Berdasarkan hal ini, organisasi sangat perlu memperhatikan work engagement pegawai mereka, terutama terhadap pekerjaan yang bergerak pada bidang layanan. Semangat dan pengabdian pegawai dalam menyelesaikan pekerjaan secara langsung akan dirasakan selama proses pelayanan. Pegawai yang bekerja pada bidang layanan merupakan garda terdepan dari suatu organisasi. Mereka mempunyai kedudukan yang berarti dan strategis, karena mereka merupakan wajah dari organisasi. Sebagai garda terdepan, pegawai yang bekerja di bidang layanan ini memiliki hak istimewa untuk melakukan 3 hal penting (Asan \& Huliselan, 2020) yaitu memahami kebutuhan pelanggan dari tangan pertama, menanggapi kebutuhan pelanggan yang unik dan beragam dalam waktu yang relatif singkat, pengetahuan dan pengalaman mereka dapat menjadi masukan pengembangan internal organisasi.

Meskipun dianggap sebagai garda depan, pada kenyataannya beberapa organisasi terkadang kurang memberikan perhatian kepada pegawai di bidang layanan. Pegawai yang bekerja pada bidang ini harus memiliki tanggung jawab dan diharapkan memiliki ketahanan mental dalam menghadapi berbagai situasi serta memberikan dedikasi yang tinggi terhadap pekerjaannya. Oleh karena itu kinerja pegawai pada bidang layanan merupakan hal yang penting dari segi layanan ataupun kontribusinya pada organisasi, keterlibatan pikiran dan emosi positif para pegawai di bidang layanan menjadi hal esensial dalam pekerjaan mereka. Hanasyah, 2016 (dilansir oleh Deby, 2021) 
menyebutkan work engagement dapat meningkatkan produktivitas kinerja pegawai baik dalam perilaku, pemikiran, emosi maupun psikologisnya. Pengaruh lain dari work engagement adalah meningkatkan loyalitas pegawai terhadap pekerjaan dan organisasi, selain itu juga dapat meningkatkan performa, ketahanan pegawai, profitabilitas dan kepuasan kerja pegawai itu sendiri (Baumarak, 2004).

Hasil penelitian yang dilakukan oleh Permatasari dan Suhariadi (2019) pada sampel Aparatur Sipil Negara (ASN) menyatakan bahwa work engagement berkontribusi dalam kesuksesan organisasi. Selanjutnya menurut Cahyati dan Qomariyah (2019) terdapat pengaruh antara work engagement terhadap kepuasan kerja pada pelayanan kefarmasian, work engagement dapat mempengaruhi kepuasan kerja karena individu merasa antusias memiliki komitmen dan termotivasi dengan pekerjaannya. Dalam kerangka kerja pegawai di bidang layanan, Teori Conservatory of Resources (COR) merupakan kerangka tambahan untuk membantu menjelaskan indikator yang dapat meningkatkan motivasi internal yang positif yang dikenal dengan work engagement (Hobfoll, 1989). Teori ini menjelaskan bahwa setiap manusia memiliki kesadaran bahwa sumber daya energi itu penting dan berharga. Oleh karena itu, secara otomatis seorang pegawai akan berupaya mendapatkan, melindungi, serta melindungi sumber dayanya yang berharga.

\section{Metode}

Penelitian ini menggunakan metode studi pustaka secara sistemik. Menurut Dickson (2017) studi pustaka sistemik bersifat intensif dan mendalam yang memerlukan tenaga, pikiran dan waktu yang cukup banyak, sebagai salah satu cara mensintesiskan temuan penelitian yang mengkaji topik permasalahan yang sama. Tujuan dari tinjauan ini adalah untuk mengeksplorasi keadaan saat ini terkait work engagement di tempat kerja, dan untuk mendapatkan inti penelitian dari literatur yang diterbitkan database elektronik mengenai pegawai di bidang pelayanan. Tinjauan ini terbatas pada literatur yang diterbitkan oleh ilmu psikologi serta manajemen. Kata kunci yang digunakan dalam pencarian literatur termasuk work engagement, petugas layanan, pegawai pemerintah dan pegawai kontrak di bidang pelayanan. Publikasi ilmiah yang akan ditinjau dalam penelitian ini diambil melalui pencarian elektronik studi ilmiah yaitu www.google scholar dan www.researchgate.com.

Penelitian terdahulu yang meneliti work engagement pada pegawai kontrak yang bekerja di bidang layanan sangat terbatas, maka penelitian yang mencakup berbagai jenis pekerjaan yang terkait pelayanan di organisasi pemerintah termasuk dalam ulasan ini. Sampel terdiri dari pre review studi penelitian yang diterbitkan dalam jurnal organisasi 
psikologi dari tahun 2017 sampai dengan tahun 2021. Kriteria pemilihan untuk tinjauan ini yaitu : (1) ditulis dalam bahasa Indonesia maupun bahasa Inggris, dan (2) work engagement di tempat kerja dalam populasi pegawai yang bekerja di bidang pelayanan milik pemerintah. Dalam review ini digunakan 9 (sembilan) artikel untuk referensi penelitian. Artikel-artikel tersebut menemukan anteseden, konsekuen serta peran mediasi dan mediator dari engagement di tempat kerja yang terkait dengan pelayanan. Tujuan penelitian, sampel dan setting, metode dan penemuan penelitian dari 9 (sembilan) artikel tersebut tercatat dalam tabel 1.

\section{Hasil}

Pada penelitian ini, beberapa artikel menyebutkan bahwa work engagement adalah semangat kerja dan keterlibatan kerja yang membuat pegawai menjadi antusias dan berdedikasi terhadap pekerjaan serta curahan energi positif individu dalam bekerja. Mengacu kepada keterlibatan dan antusias work engagement pegawai dalam bekerja, individu akan merasa terikat dan menyatu dengan tugas dan pekerjaannya, sehingga tidak terpengaruh dengan kondisi di sekelilingnya (Moura, Ramos dan Go alves (2014). Pegawai di bidang pelayanan telah diidentifikasi sebagai prediktor penting dari keberhasilan organisasi, dan work engagement pada petugas layanan memiliki peran penting yang dapat mempengaruhi kinerja mereka. Beberapa artikel menjelaskan bahwa jenis pekerjaan dan karakteristik pekerjaan dapat mempengaruhi tingkatan work engagement pada seorang pegawai (Broeck, dkk, 2017; Noesgaard \& Hansen, 2017).

Pada pegawai di bidang layanan tertentu, karakteristik khusus pada pekerjaan mereka dapat memberikan pengaruh positif dan negatif terhadap pengalaman engagement mereka, terhadap pekerjaan dan membentuk nuansa psikologi yang beragam pada diri mereka (Noesgaard \& Hansen, 2017). Faktor internal dan eksternal juga mempengaruhi work engagement pada pegawai di bidang pelayanan. Self efficacy, perceived competency, psychological well being dan self esteem berkorelasi positif terhadap work engagement (Sofiaha dan Kurniawan, 2019; Permatasari \& Suhariadi, 2019; Wardani \& Fatimah, 2020; Herlina \& Izzati, 2021). Job demand dan resource, leader-member exchange dan perceived organizational support memberikan pengaruh yang signifikan terhadap work engagement (Noesgaard \& Hansen, 2017; Junaedi, Pasinringi \& Sangkala, 2021 dan Pradnyani \& Surya, 2021). Sebagai konsekuensi dari work engagement beberapa variabel memiliki hubungan signifikan yaitu kinerja dan kepuasan kerja (Cahyati \& Qomariyah, 2019; Junaedi, Pasinringi \& Sangkala, 2021; Pradnyani \& Surya, 2021). 
Philanthropy Journal of Psychology

Vol 5 Nomor 2 (2021), 329-346

ISSN 2580-6076 (Print), ISSN 2580-8532 (Online)

Tabel 1.

Tujuan penelitian, sampel dan setting, metode dan penemuan penelitian

\begin{tabular}{|c|c|c|c|c|}
\hline $\begin{array}{l}\text { Penulis } \\
\text { tahun } \\
\text { publikasi }\end{array}$ & Tujuan & Sample & Metode & Key finding \\
\hline $\begin{array}{l}\text { Broeck, dkk } \\
\text { (2017) }\end{array}$ & $\begin{array}{l}\text { Meneliti apakah ada } \\
\text { perbedaan pegawai } \\
\text { lintas sektor dalam } \\
\text { hal tingkatan dari job } \\
\text { demand, job resource } \\
\text { dan work engagement. } \\
\text { Untuk jonguji } \\
\text { apakah job demands } \\
\text { dan job resource } \\
\text { berkaitan dengan } \\
\text { burnout dan work } \\
\text { engagement pada } \\
\text { tingkatan yang sama } \\
\text { di lintas sektor }\end{array}$ & $\begin{array}{l}2585 \text { pegawai di } \\
4 \quad \text { sektor } \\
\text { (kesehatan : } \\
571 \text {, industri : } \\
399 \text {, sektor } \\
\text { pelayanan : } 864 \\
\text { dan sektor } \\
\text { publik : 751) }\end{array}$ & $\begin{array}{l}\text { Kuesioner } \\
\text { online } \\
\text { tanpa } \\
\text { nama }\end{array}$ & $\begin{array}{l}\text { Pekerjaan dapat } \\
\text { berbeda-beda di } \\
\text { lintas sektor } \\
\text { mendasari pada } \\
\text { ketersediaan job } \\
\text { demand dan job } \\
\text { resource, serta } \\
\text { pegawai } \\
\text { menunjukkan } \\
\text { level yang } \\
\text { berbeda-beda } \\
\text { dari burnout dan } \\
\text { work engagement } \\
\text { di lintas sektor }\end{array}$ \\
\hline $\begin{array}{l}\text { Noesgaard } \\
\text { \& Hansen } \\
(2017)\end{array}$ & $\begin{array}{lr}\text { Tujuan } & \text { penelitian } \\
\text { untuk } & \text { memahami } \\
\text { work } & \text { engagement } \\
\text { pada } & \text { pegawai } \\
\text { pelayanan } & \text { publik, } \\
\text { dengan } & \\
\text { mempertimbangkan } \\
\text { persepsi r } & \text { mereka } \\
\text { terhadap } & \text { job } \\
\text { characteristic. Selain } \\
\text { itu juga } & \text { melihat } \\
\text { bagaimana } & \text { job } \\
\text { characteristic } & \\
\text { (demand r } & \text { dan } \\
\text { resource) } & \\
\text { mempengaruhi } & \\
\text { pengalaman pengasuh } \\
\text { untuk engagement } \\
\text { dengan pekerjaan. }\end{array}$ & 21 pengasuh & $\begin{array}{l}\text { Kualitatif } \\
\text { Interview } \\
\text { dan } \\
\text { observasi. }\end{array}$ & $\begin{array}{l}\text { Job characteristic } \\
\text { diasosiasikan } \\
\text { dengan } \\
\text { optimalisasi, } \\
\text { membantu orang } \\
\text { lain dan } \\
\text { pekerjaan } \\
\text { emosional. } \\
\text { Pengaruh } \\
\text { negative : } \\
\text { - Optimalisasi } \\
\text { berpengaruh } \\
\text { negatif dalam } \\
\text { pengalaman } \\
\text { engage melalui } \\
\text { rasa frustasi, } \\
\text { tidak dihargai } \\
\text { secara adil, } \\
\text { tidak ada belas } \\
\text { kasihan dalam } \\
\text { pekerjaan. } \\
\text { - Membantu } \\
\text { orang lain } \\
\text { memberikan } \\
\text { pengaruh } \\
\text { negatif terhadap } \\
\text { pengalaman } \\
\text { engagement } \\
\text { melalui tuntutan } \\
\text { kerja secara } \\
\text { mental dan fisik, }\end{array}$ \\
\hline
\end{tabular}




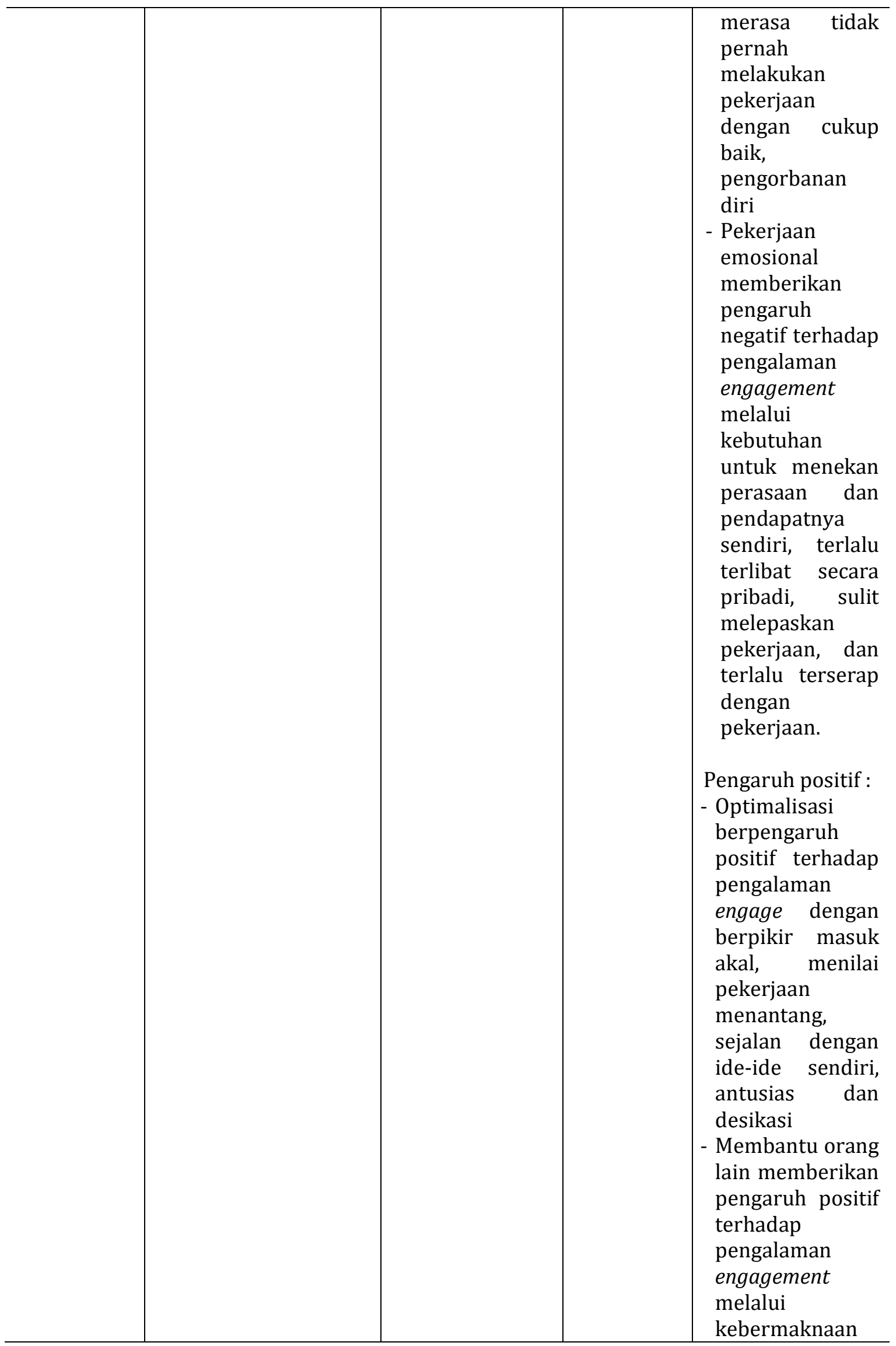




\begin{tabular}{|c|c|c|c|c|}
\hline & & & & $\begin{array}{l}\text { dan perasaan } \\
\text { penting karena } \\
\text { membantu orang } \\
\text { lain dan untuk } \\
\text { kepentingan } \\
\text { masyarakat. } \\
\text { - Pekerjaan } \\
\text { emosional } \\
\text { memberikan } \\
\text { pengaruh positif } \\
\text { terhadap } \\
\text { pengalaman } \\
\text { engagement } \\
\text { melalui } \\
\text { signifikansi, } \\
\text { membuat } \\
\text { perubahan, dan } \\
\text { kebermaknaan. } \\
\text { Kesempatan } \\
\text { untuk } \\
\text { menunjukkan } \\
\text { kasih sayang. }\end{array}$ \\
\hline $\begin{array}{l}\text { Cahyati \& } \\
\text { Qomariyah } \\
(2019)\end{array}$ & $\begin{array}{lr}\text { Menguji } & \text { kontribusi } \\
\text { work } & \text { engagement } \\
\text { terhadap } \quad \text { kepuasan } \\
\text { kerja pada karyawan } \\
\text { pelayanan } \\
\text { kefarmasian }\end{array}$ & $\begin{array}{l}69 \text { karyawan } \\
\text { pelayanan } \\
\text { kefarmasian }\end{array}$ & $\begin{array}{l}\text { Kuantitatif } \\
\text { Uji regresi } \\
\text { sederhana }\end{array}$ & $\begin{array}{l}\text { Work engagement } \\
\text { memberikan } \\
\text { kontribusi positif } \\
\text { terhadap } \\
\text { kepuasan kerja }\end{array}$ \\
\hline $\begin{array}{l}\text { Sofiaha dan } \\
\text { Kurniawan } \\
(2019)\end{array}$ & $\begin{array}{l}\text { Untuk meneliti } \\
\text { hubungan antara self } \\
\text { efficacy dengan work } \\
\text { engagement pada } \\
\text { karyawan rumah sakit }\end{array}$ & $\begin{array}{l}95 \text { orang } \\
\text { karyawan } \\
\text { Rumah Sakit St. } \\
\text { Vincentius a } \\
\text { Paulo }\end{array}$ & $\begin{array}{l}\text { Kuesioner } \\
\text { Uji } \\
\text { linearitas }\end{array}$ & $\begin{array}{l}\text { Terdapat } \\
\text { hubungan antara } \\
\text { self efficacy } \\
\text { dengan work } \\
\text { engagement pada } \\
\text { karyawan RS St. } \\
\text { Vincentius a Paulo }\end{array}$ \\
\hline $\begin{array}{l}\text { Permatasari } \\
\text { \& Suhariadi } \\
(2019)\end{array}$ & $\begin{array}{l}\text { Meneliti kondisi kerja } \\
\text { pegawai pada } \\
\text { pelayanan public } \\
\text { menggunakan leader- } \\
\text { member exchange, } \\
\text { psychological well- } \\
\text { being, and work } \\
\text { engagement }\end{array}$ & $\begin{array}{lr}80 & \text { orang } \\
\text { pegawai negeri } \\
\text { di biro } \quad \mathrm{X} \\
\text { Provinsi } & \text { Jawa } \\
\text { Timur } & \end{array}$ & $\begin{array}{l}\text { Kuantitatif } \\
\text { Kuesioner } \\
\text { Structural } \\
\text { Equation } \\
\text { Modeling- } \\
\text { Partial } \\
\text { Least } \\
\text { Square } \\
\text { (SEM-PLS) }\end{array}$ & $\begin{array}{lr}\text { Ada efek positif } \\
\text { dari } & \text { leader- } \\
\text { member exchange } \\
\text { terhadap work } \\
\text { engagement yang } \\
\text { dimediasi oleh } \\
\text { psychological well } \\
\text { being }\end{array}$ \\
\hline $\begin{array}{l}\text { Wardani \& } \\
\text { Fatimah } \\
(2020)\end{array}$ & $\begin{array}{l}\text { Meneliti } \quad \text { efek } \\
\text { performa } \\
\text { terhadap engagement } \\
\text { pada pekerja dengan } \\
\text { horizontal education } \\
\text { mismatch }\end{array}$ & $\begin{array}{l}566 \text { pekerja } \\
\text { lulusan } \\
\text { SMK/universitas } \\
\text { di Jakarta }\end{array}$ & $\begin{array}{l}\text { Kuantitatif } \\
\text { Kuesioner } \\
\text { Analisa uji } \\
\text { matriks } \\
\text { korelasi }\end{array}$ & $\begin{array}{l}\text { Perceived } \\
\text { competency } \\
\text { berpengaruh } \\
\text { secara signifikan } \\
\text { terhadap work } \\
\text { engagement. } \\
\text { Kompetensi }\end{array}$ \\
\hline
\end{tabular}




\begin{tabular}{|c|c|c|c|c|}
\hline & & & & $\begin{array}{l}\text { intelektual } \\
\text { berpengaruh } \\
\text { positif terhadap } \\
\text { work engagement, } \\
\text { terutama pada } \\
\text { dimensi vigor dan } \\
\text { dedication. }\end{array}$ \\
\hline $\begin{array}{l}\text { Junaedi, } \\
\text { Pasinringi } \\
\text { \& Sangkala } \\
\text { (2021) }\end{array}$ & $\begin{array}{l}\text { Mengetahui pengaruh } \\
\text { langsung dan tidak } \\
\text { langsung Perceived } \\
\text { Organizational } \\
\text { Support terhadap } \\
\text { kinerja dokter melalui } \\
\text { Work Engagement di } \\
\text { Rumah Sakit Umum } \\
\text { Daerah Kelas B di } \\
\text { Kota Makassar }\end{array}$ & $\begin{array}{lr}126 \text { dokter di } 3 \\
\text { RSUD } & \text { Kota } \\
\text { Makassar } & \end{array}$ & $\begin{array}{l}\text { Kuantitatif } \\
\text { Analisis } \\
\text { jalur (path } \\
\text { analysis) }\end{array}$ & $\begin{array}{l}\text { Terdapat } \\
\text { pengaruh } \\
\text { perceived } \\
\text { organizational } \\
\text { support terhadap } \\
\text { kinerja dan work } \\
\text { engagement } \\
\text { dokter. Work } \\
\text { Engagement } \\
\text { berpengaruh } \\
\text { terhadap kinerja } \\
\text { dokter. Work } \\
\text { engagement tidak } \\
\text { memediasi antara } \\
\text { hubungan antara } \\
\text { perceived dan } \\
\text { organizational } \\
\text { support kinerja dokter. }\end{array}$ \\
\hline $\begin{array}{l}\text { Pradnyani } \\
\text { \& Surya } \\
\text { (2021) }\end{array}$ & \begin{tabular}{lr}
\multicolumn{3}{l}{ Menganalisis efek dari } \\
LMX dan work \\
engagement terhadap \\
kinerja karyawan. \\
Efek dari $r$ LMX \\
terhadap rork \\
engagement, dan \\
peran mediasi work \\
engagement terhadap \\
hubungan antara LMX \\
dan kinerja pegawai.
\end{tabular} & 89 pegawai & $\begin{array}{l}\text { Interview, } \\
\text { membagik } \\
\text { an } \\
\text { kuesioner } \\
\text { dan } \\
\text { observasi. } \\
\text { Path } \\
\text { analysis } \\
\text { dan single } \\
\text { test }\end{array}$ & $\begin{array}{l}\text { LMX berpengaruh } \\
\text { positif signifikan } \\
\text { terhadap kinerja } \\
\text { karyawan dan } \\
\text { work engagement, } \\
\text { work engagement } \\
\text { berpengaruh } \\
\text { positif signifikan } \\
\text { terhadap kinerja } \\
\text { karyawan dan } \\
\text { work engagement } \\
\text { secara parsial } \\
\text { memediasi } \\
\text { pengaruh LMX } \\
\text { terhadap kinerja } \\
\text { karyawan }\end{array}$ \\
\hline $\begin{array}{l}\text { Herlina\& } \\
\text { Izzati } \\
\text { (2021) }\end{array}$ & $\begin{array}{l}\text { Mengetahui hubungan } \\
\text { antara self-esteem } \\
\text { dengan work } \\
\text { engagement pada } \\
\text { pegawai Dinas "X }\end{array}$ & 40 pegawai & $\begin{array}{l}\text { Kuantitatif } \\
\text { Korelasi } \\
\text { product } \\
\text { moment }\end{array}$ & $\begin{array}{lr}\text { Terdapat } & \\
\text { hubungan } & \text { yang } \\
\text { positif } & \text { dan } \\
\text { signifikan antara } \\
\text { self-esteem } \\
\begin{array}{l}\text { dengan } \\
\text { engagement }\end{array} \\
\end{array}$ \\
\hline
\end{tabular}


Work engagement muncul sebagai upaya pengembangan dari konsep-konsep sebelumnya seperti kepuasan kerja karyawan, komitmen karyawan, serta perilaku organisasi karyawan, dimana konsep ini pertama kali muncul pada 1990-an dan barubaru ini tercatat dalam dunia kerja di bidang pelayanan dan pemerintah. Kahn (Schaufelli, 2012) mengasumsikan engagement sebagai hasil yang positif, pada tingkat individu (pertumbuhan dan perkembangan pribadi) ataupun pada tingkat organisasi (kualitas kerja). Selain itu work engagement juga dipandang sebagai antitesis positif dari burnout. Berbeda dengan kelelahan, pegawai dengan work engagement memiliki hubungan yang energik dan efektif terhadap pekerjaan dan melihat tuntutan pekerjaan sebagai tantangan (Schaufelli, 2012).

Herlina dan Izzati (2021) melakukan penelitian terhadap Aparatur Sipil Negara (ASN). Sebagai abdi masyarakat yang memiliki banyak tugas dan tanggung jawab, ASN diharapkan memiliki ketahanan mental dalam menghadapi beban kerja yang tinggi, sehingga akan tetap semangat dalam berbagai situasi serta memberikan dedikasi yang tinggi terhadap pekerjaanya. Dedikasi menjadi salah satu aspek dari work engagement yang mengacu pada tingkat keterlibatan terhadap pekerjaan yang ditandai dengan munculnya rasa antusias terhadap pekerjaan, menganggap pekerjaan sebagai inspirasi serta menyukai tantangan dalam bekerja (Bakker \& Leiter, 2010). Pegawai dengan work engagement lebih mempunyai perasaan senang serta lebih menikmati pekerjaan tanpa adanya tekanan maupun paksaan. Work engagement ASN akan semakin menurun dengan bertambahnya masa kerja pegawai di pelayanan.

Keterlibatan pegawai secara aktif di organisasi, menunjukkan bahwa pegawai tersebut memiliki dedikasi yang tinggi terhadap organisasi sehingga pegawai tersebut memiliki kemauan untuk bekerja melebihi porsi ataupun batas pekerjaan yang diberikan organisasi (Sofiaha dan Kurniawan, 2019). Sejalan dengan penelitian ini, Permatasari \& Suhariadi (2019) menyebutkan bahwa pegawai yang memiliki work engagement akan terdorong untuk menyelesaikan pekerjaannya meskipun ada banyak rintangan. Selain itu terdapat peran pemimpin dalam work engagement dengan dimediasi oleh kesejahteraan psikologis. Kesejahteraan psikologis membuat pegawai merasa dihargai dan diterima, sehingga memunculkan pemikiran yang positif terkait pekerjaannya. Work engagement akan muncul karena pegawai merasa lebih percaya diri, tangguh dan optimis dalam menyelesaikan pekerjaan dan tantangan yang ada.

Hasil penelitian Dewi et al., 2019, menyebutkan bahwa hubungan karyawan dengan atasan, yang dikenal dengan Leader-Member Exchange (LMX), merupakan konsep yang 
menjelaskan pengaruh kepemimpinan yang efektif melalui kelompok hubungan antara atasan dan bawahan. Penelitian ini menunjukkan jika LMX tinggi, maka pegawai akan mendapat dukungan dari atasan baik secara formal maupun informal dan dapat keterbukaan dalam berkomunikasi sehingga akan meningkatkan work engagement dalam bekerja Penelitian ini juga menjelaskan bahwa work engagement dapat memediasi LMX terhadap kinerja pegawai, dengan kata lain peningkatan kualitas LMX akan meningkatkan work engagement yang pada akhirnya akan meningkatkan kinerja pegawai.

Junaedi, Pasinringi \& Sangkala (2021), menyimpulkan bahwa work engagement berpengaruh terhadap kinerja dokter, namun tidak memediasi dukungan organisasi terhadap kinerja dokter. Dukungan organisasi mengarah pada penilaian pegawai terkait sejauh mana organisasi menilai kontribusi mereka dan peduli terhadap kesejahteraan mereka. Berbeda dengan work engagement, yang lebih mementingkan energi dan fokus, sehingga memungkinkan pegawai untuk mengerahkan potensi yang dimiliki pada pekerjaannya, dan melupakan tekanan serta kesulitan yang dialami.

Caesens dan Stinglhamber (2014) menyebutkan bahwa tingkatan work engagement yang tinggi akan membawa dampak yang positif, baik pekerjaan maupun pengalaman dalam menyelesaikan pekerjaan. Sejalan dengan ini, Cahyati dan Qomariyah (2019) menunjukkan bahwa work engagement memiliki pengaruh terhadap kepuasan kerja pada pelayanan kefarmasian. Sumbangan yang diberikan oleh work engagement terhadap kepuasan kerja sebesar 13\%, sedangkan sisanya disebabkan oleh faktor lain yang dapat mempengaruhi kepuasan kerja.

Menurut Septiadi dkk (2017) semakin tinggi work engagement pegawai dalam suatu pekerjaan maka tingkat kinerja pegawai akan semakin tinggi pula. Pradnyani \& Surya (2021) menemukan bahwa semakin tinggi work engagement pegawai, semakin baik pula kinerja pegawainya. Work engagement sebagai daya saing dan keberhasilan organisasi, dalam hal ini work engagement menunjukkan adanya keinginan untuk melakukan ekstra usaha dalam bekerja (Caserio \& Chambel, 2017). Work engagement memfasilitasi pegawai untuk lebih memberikan kinerja dan energi yang positif untuk organisasi, dan secara emosional maupun psikologis lebih terikat dengan pekerjaannya.

Pernyataan ini diperkuat dengan penelitian Christian et al (2011) yang menyebutkan work engagement diyakini dapat meningkatkan kinerja, kegigihan serta mutu pegawai. Dampak positif tersebut membuat pegawai lebih merasa puas serta aman dengan pekerjaanya, selain itu work engagement diyakini juga dapat meningkatkan rasa disiplin dalam bekerja. Work engagement tidak hanya memberikan dampak positif kepada 
pegawai, tetapi juga berdampak kepada organisasi, dimana loyalitas dan kepuasan pegawai dalam menjalani pekerjaannya akan meningkatkan keinginan pegawai untuk memberikan kontribusi ekstra kepada organisasi.

Schaufeli dan Bakker (2010) telah mendefinisikan work engagement sebagai sikap positif individu untuk merasa terlibat seutuhnya dengan pekerjaan yang ditandai dengan terdapatnya aspek vigour, dedication, serta absorption. Vigour(semangat) merupakan energi besar yang dimiliki individu kala bekerja, menekankan pada usaha individu untuk senantiasa semangat, tekun dalam bekerja meski dalam kondisi yang sulit sekalipun. Dedication(pengabdian) mengacu pada tingkat keterlibatan yang tinggi, ditandai dengan timbulnya rasa antusias terhadap pekerjaan, menganggap pekerjaan sebagai inspirasi dan menyukai tantangan dalam bekerja. Absorption (penghayatan) mengacu pada individu sepenuhnya berkonsentrasi, dan menikmati pekerjaannya, tidak menyadari waktu yang dihabiskan saat bekerja dan sulit membebaskan diri dari pekerjaan (Schaufeli \& Bakker, 2010).

Work engagement terdiri dari beberapa faktor diantaranya personal resources, job demands dan job resources (Bakker \& Demerouti, 2007). Job resources merupakan sumber daya kerja mengacu pada tuntutan pekerjaan terhadap aspek fisik, psikologis, lingkungan sosial dan lingkungan pekerjaan. Personal resources merupakan kemampuan individu dalam mengontrol dirinya dengan maksud memberikan dampak positif yang terdiri dari dimensi self-esteem, optimism dan self-efficacy. Job demands merupakan tuntutan kerja berupa tuntutan fisik, serta psikologis yang harus diupayakan dalam bekerja.Job resources merupakan sumber daya kerja mengacu pada tuntutan pekerjaan terhadap aspek fisik, psikologis, lingkungan sosial dan lingkungan pekerjaan. Job resources terdiri dari dimensi social support, supervisory coaching, autonomy, feedback, performance, dan opportunities of development.

Hasil penelitian Herlina \& Izzati (2021) menunjukkan bahwa indikator yang paling menonjol dari work engagement adalah semangat dan energi pegawai dalam bekerja dan ketekunan dalam menyelesaikan pekerjaan serta pada saat menghadapi kesulitan. Indikator selanjutnya adalah keterlibatan pegawai dalam pekerjaannya dan merasa nyaman dan menyukai pekerjaan yang dilakukannya, sehingga tidak memiliki keinginan untuk mencoba bekerja di tempat lain. Selanjutnya, indikator paling rendah dalam penelitian ini ditunjukan dengan sikap sulit melepaskan diri dari pekerjaanya,serta tidak mudah diganggu ketika berkonsentrasi dalam bekerja . 
Broeck, dkk (2017) meneliti pengaruh dari jobdemand dan resource terhadap work engagement di beberapa sektor. Pada sektor kesehatan memiliki burnout di level menengah bawah dan work engagement yang tinggi, sementara karakteristik di sektor industri memiliki nilai rata-rata terendah work engagement. Terdapat perbedaan tingkatan job demand dan job resource di antara sektor-sektor tersebut. Pada sektor kesehatan dan sektor pelayanan memiliki beban kerja yang tinggi namun juga job resource yang banyak. Sementara pada sektor industri rata-rata memiliki job resource yang rendah, sektor publik rata-rata memiliki job demand dan job resource yang rendah. Rendahnya tingkatan burnout dan tingginya work engagement pada sektor kesehatan mungkin dikarenakan kombinasi adanya job demand dan job resource yang tinggi, dibandingkan dengan sektor lainnya kesehatan mengalami beban kerja yang lebih tinggi. Beban kerja yang tinggi dilihat sebagai job demand yang menantang yang pada akhirnya mendorong work engagement saat dikombinasikan dengan pemanfaatan keterampilan yang tinggi.

Pada sektor publik memiliki tingkatan job demand dan job resource yang rendah. dibandingkan dengan sektor lainnya, pekerjaan sektor publik cenderung pasif. Kondisi ini berpengaruh pada kesehatan mental dimana rata-rata pegawai di sektor publik menunjukkan nilai burnout yang tinggi dan tingkatan work engagement yang rendah. Hal ini dapat disebabkan karena kurangnya tantangan pekerjaan dan dukungan sumberdaya yang rendah. Penelitian ini memperlihatkan bahwa job demand dan job resource dapat memprediksikan work engagement, namun tidak sebaliknya.

Noesgaard \& Hansen (2017) melakukan penelitian di bidang pelayanan, dalam hal ini adalah pengasuh. Persepsi pengasuh terhadap karakteristik pekerjaan dapat memberikan pengaruh work engagement. Pada penelitian ini, pengasuh memberikan tiga tema berdasarkan persepsi pengasuh terhadap karakteristik pekerjaan mereka, yaitu optimalisasi, membantu orang lain, dan emosional pada pekerjaan. Pengasuh mengalami optimalisasi sebagai dampak dari meningkatnya proses hemat biaya, tekanan waktu dan pengukuran kerja, regulasi, aktivitas peningkatan kesehatan dan hal-hal untuk tujuan efisiensi. Bagi beberapa pengasuh, optimalisasi cenderung menyebabkan frustasi saat inisiatif, pengukuran waktu dan regulasi tidak berpihak pada kepentingan pasien yang membuat pengasuh merasa mengecewakan pasien. Disisi lain terdapat pengasuh yang memiliki persepsi positif terhadap optimalisasi dan secara positif berpengaruh terhadap pengalaman work engagement. Membantu orang lain adalah kesempatan untuk membantu pasien yang membutuhkan, yang merupakan tema utama untuk memahami nuansa pekerjaan pengasuh. Kesempatan membantu orang lain kadang membuat pengasuh 
mengabaikan perasaan dan kebutuhannya. Hal ini dapat membuat pengasuh mencapai batasan emotional resource yang dapat beresiko burnout (Maslach, Leiter \& Schaufeli, 2009) yang merupakan kebalikan dari work engagement. Sebaliknya dengan membantu orang lain pengasuh melihat bahwa pekerjaannya sangat bermakna dan signifikan karena mereka dapat membantu tidak hanya kebutuhan pasien namun juga memberikan pelayanan yang baik secara umum kepada masyarakat melalui pekerjaannya.

Keinginan untuk menampilkan kasih sayang dapat membantu menjelaskan pandangan negatif dari job demand pada pekerjaan pengasuh (mis. tuntutan kerja atau pasien yang meninggal) yang mana dapat berkontribusi positif terhadap engagement. Ketiga adalah emosional dalam pekerjaan yang digambarkan dengan bagaimana mereka dituntut untuk menekan dan berpura-pura dalam hal perasaan. Mereka dapat menjadi terikat dengan pasien secara emosi dan sering harus menghadapi tantangan situasi saat pasien mereka menderita sakit yang sangat serius. Beberapa penelitian menyebutkan bahwa keterlibatan diri ini sering dilihat sebagai pekerjaan pengasuhan yang menguras emosi (Hochschild, 2003; Hochschild, 2004). Keterlibatan diri dan dedikasi terhadap pekerjaan mirip dengan bagaimana proses engagement terjadi. Proses engagement juga melibatkan keterlibatan diri, dedikasi dan antusiasme dalam pekerjaan (Hallberg \& Schaufeli, 2006). Seorang pekerja bagaimanapun harus dapat melepaskan dirinya secara psikologis dari pekerjaan mereka agar dapat memulihkan diri (Schaufeli, Taris, \& Van Rhenen, 2008) dan membangun sumber energi kembali (Bakker, 2015).

\section{Simpulan}

Work engagement masih menjadi topik yang menarik untuk diteliti sampai dengan saat ini, karena pegawai menjadi aspek penting untuk memastikan organisasi dapat berkembang ataupun tidak. Oleh karena itu organisasi mulai memberikan perhatian yang lebih kepada manusia sebagai human capital untuk dikelola secara sungguh-sungguh. Penelitian work engagementdi sektor publik cukup banyak menarik perhatian. Pegawai pelayanan publik memiliki karakteristik yang berbeda dengan pegawai sektor lainnya, baik dari pola kerja maupun dari lingkungan pekerjaan. Beberapa hasil penelitian menunjukkan bahwa work engagement banyak dipengaruhi oleh faktor internal. Sofiaha dan Kurniawan (2019); Cahyati dan Qomariyah (2019) mendapati work engagement akan diperoleh jika pegawai memiliki pemahaman diri yang baik. Pemahaman atau pengenalan akan diri sendiri digambarkan sebagai self efficacy. Alwisol (2009) menggambarkan self efficacy sebagai penilaian diri, apakah dapat melakukan tindakan yang baiak atau buru, 
tepat atau salah, bisa atau tidak bisa mengerjakan sesuai dengan yang telah ditetapkan. Self efficacy akan mempengaruhi dan mengubah perilakunya.

Pegawai yang memiliki self efficacy yang baik akan lebih percaya diri dan yakin dapat menyelesaikan permasalahan serta memperoleh hasil kerja yang baik, dengan begitu akan memunculkan rasa puas karena telah melaksanakan pekerjaannya dengan baik. Pegawai yang memiliki kepuasan kerja cenderung akan rajin bekerja dan juga menyukai pekerjaannya, sehingga dapat memberikan kontribusi positif terhadap organisasi dengan memperhatikan kualitas kerja yang dihasilkan.

Citradewi dan Seobandono (2017) menemukan bahwa yang dapat mempengaruhi kepuasan kerja adalah work engagement dan modal psikologis, namun yang cukup besar berpengaruh adalah work engagement. Seorang pegawai yang memiliki work engagement yang tinggi akan fokus pada pekerjaannya, dan merasa menjadi bagian dari organisasi. Pegawai yang memiliki self efficacy akan dapat mengembangkan engaged organisasi ditempat ia bekerja, dan terdorong untuk menyelesaikannya meskipun banyak rintangan (Sofiaha \& Kurniawan, 2019; Permatasari \& Suhariadi, 2019). Seorang pegawai akan terus memperbaiki diri dan meningkatkan kemampuannya agar dapat mencari penyelesaian permasalahan yang dihadapi. Hal ini dapat ditunjukkan dari keinginan pegawai tersebut untuk selalu berupaya, gigih dan tidak mudah putus asa menyelesaikan permasalahan yang dihadapi. Pegawai dengan kompetensi intelektual, memiliki energi yang besar dan merasa tertantang dalam menyelesaikan pekerjaannya. Keberhasilan pegawai tersebut dalam menyelesaikan pekerjaan yang sulit akan membuatnya mendapatkan penilaian yang positif dari lingkungan sosialnya.

Penilaian positif yang diperoleh akan meningkatkan harga diri, rasa percaya diri dan menimbulkan semangat serta rasa nyaman dalam bekerja. Hal lain dari timbulnya rasa nyaman dalam bekerja adalah munculnya kesejahteraan psikologis pada pegawai. Kesejahteraan psikologis yang dimiliki pegawai akan membuat pegawai mampu bertahan dan berinteraksi dalam situasi yang penuh tekanan. Kesejahteraan psikologis juga akan dapat menjadi sumber motivasi, sehingga membuat pegawai melihat segala yang terjadi sebagai suatu yang postif meskipun dalam situasi yang sulit, dengan begitu akan membuat pegawai menjadi engaged dengan pekerjaannya dan juga organisasi tempatnya bekerja (Permatasari \& Suhariadi, 2019; Wardani \& Fatimah, 2020; Herlina \& Izzati, 2021).

Faktor ekternal juga mempunyai peran penting dalam mempengaruhi work engagement pegawai, antara lain dukungan organisasi dan peran pemimpin. Organisasi diharapkan dapat menciptakan iklim kerja yang nyaman dan memberikan penghargaan 
kepada pegawainya, selain itu hubungan interaksi yang baik antara pemimpin dan bawahannya akan memberikan respon yang positif kepada bawahannya. Pimpinan dapat memberikan informasi dan evaluasi yang diperlukan dengan leluasa, sedangkan pegawai akan mendapat dukungan dari atasannya baik secara formal maupun informal sehingga pegawai akan arti dalam bekeja, komitmen dan serta merta akan meningkatkan work engagement (Pradnyani \& Surya, 2021; Junaedi, Pasinringi \& Sangkala, 2021).

Work engagement terdiri dari bebarapa faktor diantaranya personal resources, job demands dan job resources (Bakker \& Demerouti, 2007). Job resources merupakan sumber daya kerja mengacu pada tuntutan pekerjaan terhadap aspek fisik, psikologis, lingkungan sosial dan lingkungan pekerjaan. Personal resources merupakan kemampuan individu dalam mengontrol dirinya dengan maksud memberikan dampak positif yang terdiri dari dimensi self-esteem, optimism dan self-efficacy. Job demands merupakan tuntutan kerja berupa tuntutan fisik, serta psikologis yang harus diupayakan dalam bekerja. Pada penelitian yang dilakukan oleh Noesgaard \& Hansen, 2017; Broeck, dkk, 2017, menunjukan bahwa karakteristik pekerjaan, job demand dan job resourcememberikan pengaruh terhadap work engagement seorang pegawai. Pada sektor publik, yang memiliki karakteristik pekerjaan berupa optimalisasi, membantu orang lain, dan emosional pada pekerjaan, dengan job demands dan job resources yang rendah, akan membuat pegawai memiliki work engagement yang rendah pula. Pada sektor ini sebagaian besar organisasi tidak banyak memiliki tuntutan fisik kepada pegawainya. Selain itu organisasi juga tidak memilki tuntantan psikologis yang tinggi terhadap pegawai, hal ini membuat pegawai merasa tidak memiliki tantangan dalam menjalani pekerjaannya.

\section{Saran}

Penelitian work engagement di sektor pelayanan publik lebih banyak mengangkat Aparatur Sipil Negera (ASN). Kedepan dapat dilakukan penelitian kepada pegawai NonASN yang menghadapi situasi kerjayang sama dengan ASN,namun memiliki perbedaan baik dalam dukungan organisasi, tunjangan dan kesempatan berkembang serta tuntutan kerja. Nuansa psikologis dalam bekerja dan mengembangkan engagement akan memiliki karakteristik tersendiri. Penulis dapat menyarankan untuk penelitian kedepan guna mengembangkan teori job characteristic, work engagement dan psychological wellbeing dengan mencari hubungan dari ke tiga faktor tersebut.

\section{Kepustakaan}


Abbas, M. (2017). The Effect Of Organizational Culture And Leadership Style Towards Employee Engagement And Their Impact Towards Employee Loyalty. Asian Journal of Technology and Management Research, 7(7), 1-11.

Asan,Sucipto., Huliselan, J. J..(2020). Analisis Work Engagement Karyawan Frontline HighContact Dan Low-Contact Di Industri Jasa. Jurnal Manajemen Maranatha, Volume 19, Nomor 2, Mei 2020, pp 127-140

Ayu, Diah. R, Maarif, S., \& Sukmawati, A. (2015). Pengaruh job demand, job resources dan personal resources terhadap work engagement. Jurnal Aplikasi Bisnis Dan Manajemen, 1(1), 12-22.

Alwisol, (2009). Psikologi Kepribadian. Malang : UMM Press

Bakker.A.B., \& M. P. L. (2010). Work engagement : A handbook of essential theory and research. In ISSN 2502-3632 (Online) ISSN 2356-0304 (Paper) Jurnal Online Internasional \& Nasional Vol. 7 No.1, Januari - Juni 2019 Universitas 17 Agustus 1945 Jakarta (Vol. 53, Issue 9, pp. 1689-1699).

Bakker, A. B. (2011). An evidence-based model of work engagement. Current directions in psychological science, 20(4), 265-269.

Bakker, A. B. (2015). Towards a multilevel approach of employee well-being. European Journal of Work and Organizational Psychology, 24(6), 839-843. doi:10.1080/ 1359432X.2015.1071423

Bakker, A. B. (2017). Strategic and proactive approacher to work engagement. Organizational Dyanamic, 46(1), 67-75.

Baumruk, R. (2004). The missing link: The role of Employee Engagement In Business Succes. Workspan, 47(11), 48-52.

Berger, A. (2010). Review: Happiness at work. USA: Basil \& Spice.

Broeck, et al. (2017). Job Demands, Job Resources, Burnout, Work Engagement, and Their Relationships: An Analysis Across Sectors. American College of Occupational and Environmental Medicine, Volume 59, Number 4.

Caesens, G., \& Stinglhamber, F. (2014). The relationship between perceived organizational support and work engagement: The role of self-efficacy and its outcomes. Revue Européenne de Psychologie Appliquée/European Review of Applied Psychology, 64(5), 259-267.

Cahyati.S, dan Qomariyah., N. (2019)Peran Work Engagement Terhadap Kepuasan Kerja Pada Karyawan Pelayanan Kefarmasian Di Rumah Sakit. Jurnal Psikologi Volume 12 No.1.

Citradewi, A., \& Soebandono, J. P. (2017). Pengaruh totalitas kerja dan modal psikologis terhadap kepuasan kerja driver Gojek di Jakarta Selatan. Journal of Psychology, 22(2), 151-164.

Dickson, R. (2017). Doing A Systematic Review: A Student Guide. Sage Publications Limited.

Gutermann, D., Lehmann- Willenbrock, N., Boer, D., Born, M., \& Voelpel, S. C. (2017). How Leaders Affect Followers' Work Engagement and Performance : Integrating LeaderMember Exchange and Crossover Theory. British Journal of Management, 28(2), 299-314.

Hallberg, U. E., \& Schaufeli, W. B. (2006). "Same same" but different? European Psychologist, 11(2), 119-127. doi:10.1027/1016-9040.11.2.119

Herlina, D.A. \&Izzati,U., A. (2021) Hubungan Antara Self- Esteem Dengan Work Engagement Pada Pegawai Dinas "X". Jurnal Penelitian Psikologi. Volume 8 Nomor 5.

Hobfoll, S.E. (1989). Conservation of resources: a new attempt at conceptualizing stress. American Psychologist, Vol.44, 513-524

Hochschild, A. R. (2003). Behind every great caregiver. The emotional labour in health care. In L. Dubé, \& G. Ferland (Eds.), Emotional and interpersonal dimensions of 
health services: Enriching the art of care with the science of care (pp. 67-72). Montreal, Canada: McGill-Queen's PressMQUP.

Hochschild, A. R. (2004). Emotional labour in health care: Who takes care of the caretaker? In L. Dubé, G. Ferland, \& D. S. Moskowitz (Eds.), Enriching the art of care with the science of care: Emotional and interpersonal dimensions of health services (pp. 6772). Montreal, Canada: McGill Queen's University Press.

Jin, M. H., \& McDonald, B. (2017). Understanding employee engagement in the public sector: The role of immediate supervisor, perceived organizational support, and learning opportunities. The American Review of Public Administration, 47(8), 881897.

Kaufman, J., Markey, R., Burton, S.D., \& Azzarello, D. (2013). Who's responsible for employee engagement. Diperoleh dari: http://www.bain.com/publications/articles/whosresponsible-for-employee-engagement.aspx

Kong, Y. (2009). A study on the job engagement of company employees. International Journal ofPsychological Studies, 1(2), 65-68. https://doi.org/10.5539/ijps.v1n2p65

Junaedi, A.A.S.,Pasinringi., S.A., Sangkala. (2021). Pengaruh Perceived Organizational Support Terhadap Kinerja Dokter Melalui Work Engagement Di Rumah Sakit Umum Daerah Kelas B Di Kota Makassar. The Effect Of Perceived Organizational Support On Doctor Performance Through Work Engagement In Public Regional Hospital At Makassar City. Jurnal Ilmiah Ecosystem, Volume 21 Nomor 1, Januari - April 2021

Maslach, C., Schaufeli, W. B., \& Leiter, M. P. (2001). Job burnout. Annual Review of Psychology, 52(1), 397-422. doi:10.1146/annurev.psych.52.1.397.

Messias, F., Mendes, J., \& Monteiro, I. (2010). The effects of leadership behaviors on the employee wellbeing in the workplace: a worthy investment from managers or leaders.

Moura, D., Ramos, A. O., \& Go alves, G. (2014). Role stress and work engagement as antecedents of job satisfaction. Europe's Journal of Psychology, 10(2), 291-300.

Nazir, O., \& Islam, J. U. (2017). Enhancing Organizational Commitment and Employee Performance https://www.researchgate.net/publication/230580677

Noesgaard., M.S. \& Hansen., J.R. (2017). Work Engagement in the Public Service Context: The Dual Perceptions of Job Characteristics. International Journal of Public Administration, DOI: 10.1080/01900692.2017.1318401

Permatasari., W.Y, dan Suhariadi., F. (2019). Leader-Member Exchange Affects Work Engagement: The Role Of Psychological Well-Being Mediation. Psikohumaniora: Jurnal Penelitian Psikologi, Vol 4, No 1 (2019): 95-114.

Pradhan, R. K., \& Jena, L. K. (2017). Employee Performance at Workplace: Conceptual Model and Empirical Validation. Business Perspectives and Research, 5(1), 69-85.

Sartono, H., \& Ardhani, M. (2017). Work engagement, intrinsic motivation and job satisfaction among employees of a coal mining company in South Borneo. International Research Journal of Business Studies, 8(2), 107-122. https://doi.org/10.21632/irjbs.8.2.107-122

Septiadi, S. A., Sintaasih, D. K., \& Wibawa, I. M. A. (2017). Pengaruh Keterlibatan Kerja terhadap Kinerja dengan Pemediasi Komitmen Organisasional. E-Jurnal Ekonomi Dan Bisnis Universitas Udayana, 6(8), 3103-3132.

Sofiaha, D., dan Kurniawan, G. (2019). Hubungan Self-Efficacy Dengan Employee Work Engagement Pada Karyawan. Jurnal Fenomena, Vol. 28 No. 1, hal. 54-61

Schaufeli, W. B., Bakker, A. B., \& Salanova, M. (2006). The measurement of work engagement with a short questionnaire: A cross-national study. Educational and Psychological Measurement, 66(4), 701-716.

Schaufeli, W. B., Taris, T. W., \& Van Rhenen, W. (2008). Workaholism, Burnout, And Work Engagement: Three Of A Kind Or Three Different Kinds Of Employee Well-Being? Applied Psychology, 57(2), 173-203. doi:10.1111/j.1464- 0597.2007.00285. 
Schaufeli, W. B. (2013). What is engagement? In C. Truss, K. Alfes, R. Delbridge, A. Shantz, \& E. Soane (Eds.), Employee engagement in theory and practice. London: Routledege.

Schaufeli, W.B.. (2012). Work Engagement. What Do We Know and Where Do We Go?. Romanian Journal of Applied Psychology, Vol. 14, No. 1, 3-10.

Septiadi, S. A., Sintaasih, D. K., \& Wibawa, I. M. A. (2017). Pengaruh Keterlibatan Kerja terhadap Kinerja dengan Pemediasi Komitmen Organisasional. E-Jurnal Ekonomi Dan Bisnis Universitas Udayana, 6(8), 3103-3132.

Wardani, L.M.I., dan Fatimah. S. (2019). Kompetensi Pekerja dan Efeknya terhadap Work Engagement: Riset pada Pekerja dengan Horizontal Education Mismatch. Jurnal Psikologi Sosial, Vol. 18, No. 1, 73-85. DOI: 10.7454/jps.2020.09 2020 